\title{
Physiological performance and expression of isozymes in maize seeds subjected to water stress ${ }^{1}$
}

\author{
Viviane Maria de Abreu ${ }^{2 *}$, Édila Vilela de Resende Von Pinho ${ }^{3}$, Renzo Garcia Von \\ $\mathrm{Pinho}^{3}$, Glória Maria de Freitas Naves 2 , Izabel Costa Silva Neta ${ }^{4}$, \\ Renato Mendes Guimarães ${ }^{3}$, Marcela Rezende de Carvalho ${ }^{2}$
}

\begin{abstract}
Early characterization of genotypes, through the previous assessment of physiological quality of their seeds and their enzymatic systems, can provide parameters capable of aiding in the selection of new maize cultivars tolerant to water stress. Thus, this study was aimed at assessing seed performance of five different maize lines subjected to four different water stress levels. The physiological quality of seeds germinated under the osmotic potentials of $0.0,-0.3,-0.6$ and $-0.9 \mathrm{MPa}$ was assessed by germination test, number of strong normal seedlings and T50, as well as by the expression of the isozymes superoxide dismutase (SOD), catalase (CAT), glutamate oxaloacetate transaminase (GOT), esterase (EST), malate dehydrogenase (MDH), alcohol dehydrogenase (ADH), and of heat-resistant proteins. The osmotic potential of $-0.9 \mathrm{MPa}$ affected the physiological quality and vigor of seeds of all maize lines assessed. The highest values for the germination percent, in the lowest osmotic potentials assessed, were found in the seeds of line 63. However, seeds of line 91 were superior in regard to vigor. Increased expression of the enzymes SOD and CAT, considered as enzymes of the antioxidant system, was observed in seeds of lines 44 and 91 . Thus, line 91 was considered as promising for tolerance to water stress.
\end{abstract}

Index terms: physiological quality, water deficit, drought tolerance.

\section{Desempenho fisiológico e expressão de isoenzimas em sementes de milho submetidas ao estresse hídrico}

\begin{abstract}
RESUMO - A caracterização precoce de genótipos, por meio de avaliação prévia da qualidade fisiológica de suas sementes e seus sistemas enzimáticos, pode fornecer parâmetros capazes de auxiliar na seleção de novas cultivares de milho tolerantes ao estresse hídrico. Assim, o objetivo deste estudo foi avaliar o desempenho das sementes de cinco linhagens de milho submetidas à quatro níveis de estresse hídrico. Para isso, a qualidade fisiológica das sementes, germinadas sob os potenciais osmóticos de 0,$0 ;-0,3 ;-0,6$ e - $0,9 \mathrm{MPa}$, foi avaliada pelo teste de germinação, número de plântulas normais fortes e T50, bem como pela expressão das isoenzimas superóxido dismutase (SOD), catalase (CAT), glutamato oxalacetato transaminase (GOT), esterase (EST), malato desidrogenase (MDH), álcool desidrogenase $(\mathrm{ADH})$ e de proteínas resistentes ao calor. O potencial osmótico de $-0,9 \mathrm{MPa}$ afetou a qualidade fisiológica, bem como o vigor das sementes de todas as linhagens avaliadas. Os maiores valores para a porcentagem de germinação, nos menores potenciais osmóticos avaliados, foram observados nas sementes da linhagem 63. No entanto, sementes da linhagem 91 foram superiores quanto ao vigor. Maior expressão das enzimas SOD e CAT, consideradas como enzimas do sistema antioxidante, foram observadas em sementes das linhagens 44 e 91 . Assim, a linhagem 91 é considerada como linhagem promissora quanto à tolerância ao estresse hídrico.
\end{abstract}

Termos para indexação: qualidade fisiológica, déficit hídrico, tolerância à seca.

\section{Introduction}

The stress caused by low water availability is one of the most limiting factors to the proper development of crops.

\footnotetext{
${ }^{1}$ Submitted on 08/14/2013. Accepted for publication on 10/30/2013.

${ }^{2}$ Universidade Federal de Lavras, Caixa Postal 3037, 37200-000 - Lavras, MG, Brasil.

${ }^{3}$ Departamento de Agricultura, UFLA, Caixa Postal 3037, 37200-000 - Lavras,
} MG, Brasil.
Tolerance to water deficit conditions is variable, and its effects depend on the developmental stage of plants of the crop used for cultivation. Thereby, the previous identification of the genotypes that exhibit tolerance to such stress, in genetic
${ }^{4}$ Departamento de Fitotecnia, UFLA, Caixa Postal 3037, 37200-000 - Lavras, MG, Brasil.

*Corresponding author < vivianeabreu ufla@yahoo.com.br> 
breeding programs is essential, and justifies the studies related to water stress during seed germination in the field (Thakur and Sharma, 2005).

Physiological quality is a characteristic acquired during the seed development and may be lost trough the deteriorative processes occurring during germination; and in the presence of water stress conditions, the deterioration of such seeds is inevitable, mainly due to microorganisms present in the soil. The water deficits, which occur during germination, may even prevent, alter its period, and/or its uniformity, thereby impairing the good crop establishment in the field. However, concerning these variables, the levels of responses depend on both the degree of tolerance to this type of stress, as well as of crop species studied (Kranner et al., 2010).

Selection of genotypes, through the previous assessment of physiological quality of their seeds and their enzymatic systems, can provide parameters capable on aiding in the evaluation of new maize cultivars tolerant to water stress. Thus, the evaluation of physiological quality of maize seeds, in quality control programs are carried out mainly by specific germination tests (cold test and accelerated aging test) (Faria et al., 2002).

To assess water stress influence on development of maize seeds several studies have already been carried out. As examples it may be cited: the study of Vaz Melo et al. (2012), who observed an increase on the germination time of popcorn [Zea mays L. var. everta (Sturtev) L.H. Bailey] seeds, subjected to the water stress induced by polyethylene glycol (PEG 6000); the study performed by Avila et al. (2007), who reported a reduction in the length of maize (Zea mays L.) seedlings grown under water stress conditions, simulated by osmotic solutions; and the study carried out by Moterle et al. (2008) on the influence of drought stress on physiological performance of simple popcorn hybrids seeds, also simulated by PEG 6000, which caused until $87 \%$ reductions on percent germination of the assessed seeds.

The physiological quality of maize seeds has been linked to the expression of enzymes that are assessed by electrophoresis techniques (Brandão-Junior et al., 1999). The use of these isozymes is justified, since their polymorphisms are closer to the final phenotypic expression than the DNA polymorphisms (Torggler et al., 1995; Souza et al., 2005), making the selection more efficient according to the new gene concept (Resende et al., 2011).

Water stress triggers several key biochemical and physiological processes, and also affects the antioxidant defense system enzymes, thus causing accumulation of reactive oxygen species (ROS) such as the hydrogen peroxide $\left(\mathrm{H}_{2} \mathrm{O}_{2}\right)$, as well as of free radicals as superoxide $\left(\mathrm{O}_{2}^{-}\right)$and hydroxyl $\left(\mathrm{OH}^{-}\right)$(Manivannan et al., 2008); and ROS formation has been reported by several authors as being a product of both the biotic and abiotic stresses (Reddy et al., 2004). Usually, the plants protect their cells and their cellular compartments from the toxic effects of ROS with the aid of several antioxidant enzymes such as: superoxide dismutase (SOD); ascorbate peroxidase (APX); glutathione reductase (GSH); peroxiredoxin (PRX); catalase (CAT); and polyphenoloxidase (PPO); and ROS production, and the increases on activities of antioxidant enzymes have been considered as a plant response to water stress (Apel and Hirt, 2004). In this sense, balance between these antioxidant enzymes is fundamental for regulating ROS levels in cells.

In the enzymatic detoxification systems, the enzyme SOD acts as the first defense line against the ROS, converting the superoxide radical into hydrogen peroxide and oxygen; and in turn, the hydrogen peroxide produced by the enzyme SOD can be converted to water and oxygen by the CAT enzyme or in water by the action of APX enzyme (Noctor and Foyer, 1998).

Given the above, the aim of this study was assessing performance of different maize lines subjected to water stress.

\section{Material and Methods}

The study was carried out at the Seed Central Laboratory of the Department of Agriculture, Federal University of Lavras, Lavras, state of Minas Gerais, Brazil. Seeds of the maize lines 63, 54, 64, 44 and 91, which are genotypes from the breeding program of the company Genesseds Genetic Resources in Maize were used; before the evaluation, the seeds were treated with the fungicide Thiram ${ }^{\circledR}$-Vitavax 200 $\mathrm{SC}$ in the dosage of $300 \mathrm{~mL} .100 \mathrm{~kg}^{-1}$ seed.

On simulating the water stress, for performing the tests of seed germination and vigor, solutions of polyethylene glycol (PEG 6000) were used at the osmotic potentials of zero (control), $-0.3,-0.6$, and $-0.9 \mathrm{MPa}$; with osmotic potential of 0.0 being correspondent to the treatment with distilled water. For determining the amount of PEG 6000 to be used in the solutions, the methodology proposed by Villela et al. (1991) was used.

To assess seed physiological quality, the germination test was performed with four subsamples of 50 seeds each, to each replication of each treatment. The seeds were distributed upon sheets of towel paper moistened with PEG 6000 solutions in the different levels of osmotic potential previously established, and in a ratio equivalent to 2.5 times the mass of the dry substrate, and made into rolls; which were then kept into plastic bags throughout all the test period to avoid water evaporation and to ensure the desired osmotic potential. Subsequently, the seeds were placed to germinate into a BOD type germination chamber, set at a $25^{\circ} \mathrm{C}$ constant temperature; 
and assessments were performed at seven days after test start. On the fourth day after sowing (DAS), the blotter paper sheets were replaced by new sheets, also moistened with the different PEG solutions, and the non-germinated seeds or the normal seedlings emerged were transferred to these new sheets; thus ensuring the maintenance of the osmotic potential established. On the seventh DAS, the number of germinated seeds and the number of strong normal seedlings was assessed; considering as emerged only those seedlings presenting the shoots with, at least, $2.0 \mathrm{~cm}$ long, and, at least, two secondary roots with 6.0 $\mathrm{cm}$ long. Time required for occurrence of $50 \%$ germination (T50) was also assessed.

For analysis of isozymes STS, CAT, SOD, ADH, MDH, glutamate oxaloacetate transaminase (GOT), and $\alpha$-amylase, as well as of heat resistant proteins; two sample of 10 seeds each, presenting radicle protrusion were removed from each treatment and stored into a freezer. Seeds used to assess the activity of the $\alpha$-amylase enzyme had their embryonic axes extracted and eliminated. Afterwards, seeds were manually macerated in a mortar with antioxidant polyvinylpyrrolidone (PVP) and liquid nitrogen and stored into a deep freezer, set at $-86{ }^{\circ} \mathrm{C}$ constant temperature.

For extraction of isozymes STS, CAT, SOD, ADH, MDH, and GOT, to each of the subsamples of $100 \mathrm{mg}$ of macerated were added $250 \mu \mathrm{L}$ extraction buffer Tris- $\mathrm{HCl} 0.2 \mathrm{M}(\mathrm{pH} 8.0)$ and $0.1 \%$ of $\beta$-mercaptoethanol. Macerated was then placed in a refrigerator for 12 hours, and then centrifuged at 14,000 rpm for 30 min., at $4{ }^{\circ} \mathrm{C}$. Electrophoresis was carried out in discontinuous polyacrylamide gel system $7.5 \%$ (separator gel) and $4.5 \%$ (stacking gel). Tris-glycine ( $\mathrm{pH}$ 8.9) was the buffer gel-electrode system used for the electrophoretic run. For the electrophoretic run, $50 \mu \mathrm{L}$ of each supernatant were applied to the gel grooves, and electrophoresis was carried out at $150 \mathrm{~V}$, for $4 \mathrm{~h}$, at $4{ }^{\circ} \mathrm{C}$. At the end of electrophoretic run, gels were stained with specific substrates for each enzyme (Alfenas, 2006).

For extraction of $\alpha$-amylase enzyme a $200 \mathrm{mg}$ sample of macerated seeds was re-suspended in $600 \mu \mathrm{L}$ of extraction buffer Tris- $\mathrm{HCl} 0.2 \mathrm{M}(\mathrm{pH} 8.0)+0.4 \%$ PVP. Staining of protein bands was accomplished by applying $40 \mathrm{~mL}$ of protein extract to the polyacrylamide gels $7.5 \%$ (separator gel) and $4.5 \%$ (stacking gel).

For extraction of resistant to heat proteins, to samples already macerated in buffer solution Tris- $\mathrm{HCl}(\mathrm{pH} 7.5)$ were added $500 \mathrm{mM} \mathrm{NaCl}, 5 \mathrm{mM} \mathrm{MgCl}_{2}$, and $1 \mathrm{mM}$ phenylmethylsulfonyl fluoride (PMSF) at 1:10 ratio (macerate mass: extraction buffer volume); which were then transferred into $1500 \mu \mathrm{L}$ capacity microtubes. The homogenate was centrifuged at $14,000 \mathrm{rpm}$, at $4{ }^{\circ} \mathrm{C}$, for 30 min. and supernatant was incubated in water bath at $85^{\circ} \mathrm{C}$, for
$15 \mathrm{~min}$. and again centrifuged. Supernatant was poured into microtubes and pellet was discarded. Before application to gel, the tubes with samples containing $70 \mu \mathrm{L}$ seed extract +40 $\mu 1$ sample buffer solution, composed by $2.5 \mathrm{~mL}$ glycerol; 0.46 g sodium dodecyl sulfate (SDS); $20 \mathrm{mg}$ Bromophenol Blue (BPB); and with the volume completed to $20 \mathrm{~mL}$ of Tris- $\mathrm{HCl}$ extraction buffer ( $\mathrm{pH} 7.5$ ) were placed into boiling water bath for 5 min. Subsequently, on each groove of polyacrylamide SDS-PAGE gel at $12.5 \%$ (separating gel) and 6\% (stacking gel) were applied $50 \mu \mathrm{L}$ of the extract containing the heat resistant proteins + the sample buffer solution.

Following methodology described by Alfenas (2006), electrophoretic run was performed at $150 \mathrm{~V}$, for $12 \mathrm{~h}$ and subsequently gels were stained with solution of coomassie brilliant blue at $0.05 \%$ and discolored with $10 \%$ acetic acid solution.

The experiment was carried out in a completely randomized experimental design, with treatments arranged in a factorial $5 \times 4$ (5 maize lines x 4 osmotic potentials), and four replications to each treatment. Data obtained for percent of normal seedlings emerged were transformed to $\sqrt{(x}+1)$ prior to ANOVA application. Means obtained for different maize lines were compared by Scott-Knott test ( $p$ $<0.05$ ). Analysis of data obtained for osmotic potential was performed by polynomial regression at 5\% probability. All statistical analyses were performed using statistical software Sisvar (Ferreira, 2011).

\section{Results and Discussion}

Results obtained showed significant interaction between the two variables assessed (breeding lines x osmotic potentials); thus indicating that these two factors are interacting or are dependent.

On assessing germination test only the normal seedlings emerged were counted, since this evaluation was performed aiming at differentiating among maize lines studied; and insofar seeds germinated, most of them did not produce normal seedlings in the lowest water potentials assessed. Through regression curves, plotted to mean values obtained for percent germination on the seventh DAS (Figure 1), it is observable that there was a reduction in germination percent whenever water restriction was increased. However, in the osmotic potentials of $0.0 \mathrm{MPa}$ (control) and $-0.3 \mathrm{MPa}$, the means obtained for all maize lines have behaved similarly and did not show statistically significant differences between each other. It is also noticeable that, at the $-0.6 \mathrm{MPa}$ level, the seeds of lines 63 and 44 were those presenting the highest percent germination. At this same water deficit level, seeds of the line 54 , followed by the line 64 , also had high percent germination. 
Despite the highest percent germination in the control treatment (pure distilled water) the seeds of the maize line 91 were those with the lowest germination percentages on all levels of osmotic potential assessed (Figure 1). Similar results were already obtained by Moterle et al. (2008), who reported that reduction on water potential, induced by PEG 6000 caused a reduction of until $87 \%$ in the germination percent of the maize seeds assessed. According to these authors increased substrate osmotic concentration reduces water absorption by seeds and, consequently, causes reduction on percent germination.

Through regression curves, plotted to mean result values obtained to T50 (Figure 2), it can be observed that, insofar values of osmotic potential were reduced there was also a consequent increase on T50 values; and that through mean values presented on Table 1 it is verifiable that, for treatment 0.0 MPa (control), the best results to percent normal seedlings emerged were obtained for the maize line 91, followed by lines 54,64 , and 44. In this same treatment it was observed that, for this factor, the worst performance was observed for the seeds of maize line 63; which has remained as the maize line with the worst performance when the osmotic potential was reduced to $-0.3 \mathrm{MPa}$ (Table 1). However, in the highest osmotic potential (-0.9 MPa), there was no statistically significant difference among mean values obtained for all assessed maize lines (Figure 1). Within this same context, through germination speed index (GSI) and T50, Vaz Melo et al. (2012) have also observed an increase in percent germination when the water stress was simulated with PEG 6000.

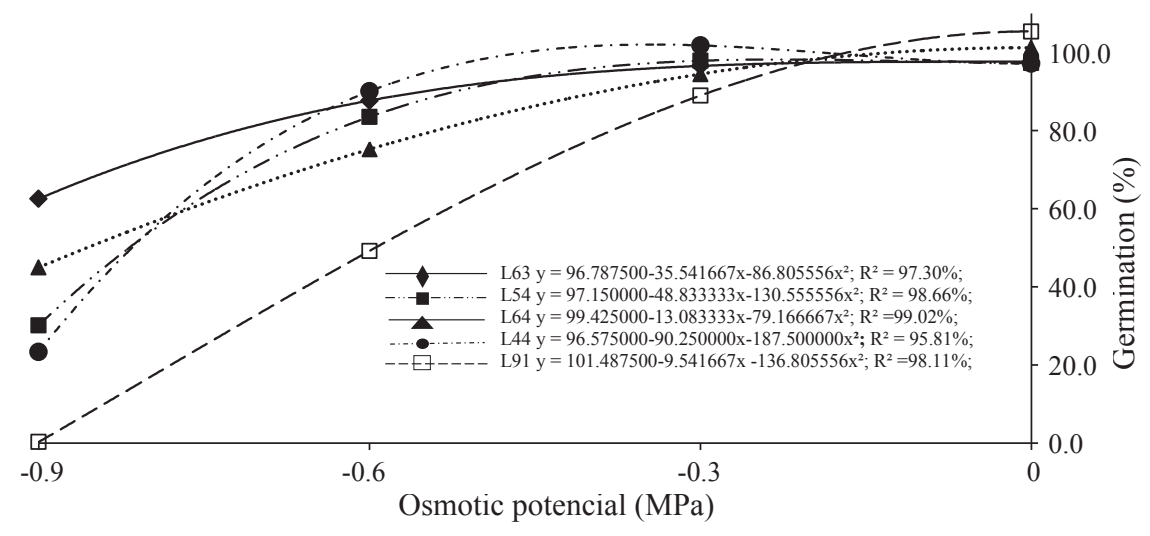

Figure 1. Graphical representation of polynomial regression curves, plotted with the means of germination percentage of seeds of five different maize lines (L63, L54, L64, L44, and L91) germinated at osmotic potentials of 0.0, -0.3, -0.6, and -0.9 MPa.



Figure 2. Time for the occurrence of $50 \%$ of germination (T50) of the maize lines $63,54,64,43$, and 91 subjected to the osmotic potentials of $0.0,-0.3,-0.6$ and $-0.9 \mathrm{MPa}$.

Through regression curves plotted with means computed with data obtained for the number of strong normal seedlings, it is observable that there was a marked reduction in the number of strong normal seedlings whenever the water restriction was increased (Figure 3). However, in the control treatment $(0.0 \mathrm{MPa})$, differences between means obtained 
for all maize lines assessed were not statistically significant. Yet, on osmotic potential of $-0.3 \mathrm{MPa}$ the number of strong normal seedlings from seeds of the line 91, followed by line 44 were the highest; thereby indicating a greater vigor level for seeds of these two maize lines. For the other lines assessed, the low values observed for this parameter indicate that those seeds had a lower vigor level; whereas the line 63 was the one presenting the worst performance. At the osmotic potentials of -0.6 and -0.9 there was no statistically significant difference between the means obtained for all maize lines assessed, both for the germination percent (Table 1) as for the absolute number (Figure 3 ) of strong normal seedlings.

Table 1. Means of germination percentage, time needed for occurrence of $50 \%$ of seed germination (T50) and percentage of strong normal seedlings, assessed on five different maize lines subjected to four different osmotic potentials (Data transformed to $\sqrt{x+1}$ before ANOVA).

\begin{tabular}{|c|c|c|c|c|c|c|c|c|c|c|c|c|}
\hline \multirow{3}{*}{ Maize line } & \multicolumn{12}{|c|}{ Parameter assessed / Osmotic Potential (MPa)* } \\
\hline & \multicolumn{4}{|c|}{ Germination $(\%)$} & \multicolumn{4}{|c|}{ T 50} & \multicolumn{4}{|c|}{ Strong normal seedlings (\%) } \\
\hline & 0.0 & -0.3 & -0.6 & -0.9 & 0.0 & -0.3 & -0.6 & -0.9 & 0.0 & -0.3 & -0.6 & -0.9 \\
\hline 63 & $98 \mathrm{a}$ & $96 \mathrm{a}$ & $88 \mathrm{a}$ & $62 \mathrm{a}$ & $2.0 \mathrm{~b}$ & $2.6 \mathrm{c}$ & $3.6 \mathrm{~d}$ & $3.3 \mathrm{a}$ & $9.9 \mathrm{a}$ & $1.7 \mathrm{~d}$ & $1 \mathrm{a}$ & $1 \mathrm{a}$ \\
\hline 54 & $98 \mathrm{a}$ & $96 \mathrm{a}$ & $84 \mathrm{a}$ & $30 \mathrm{c}$ & $1.7 \mathrm{a}$ & $2.5 \mathrm{c}$ & $3.2 \mathrm{c}$ & $3.2 \mathrm{a}$ & $9.9 \mathrm{a}$ & $2.5 \mathrm{c}$ & $1 \mathrm{a}$ & $1 \mathrm{a}$ \\
\hline 64 & $98 \mathrm{a}$ & 99 a & $73 \mathrm{~b}$ & $45 \mathrm{~b}$ & $1.6 \mathrm{a}$ & $2.4 \mathrm{~b}$ & $3.4 \mathrm{~d}$ & $3.5 \mathrm{a}$ & $9.9 \mathrm{a}$ & $2.4 \mathrm{c}$ & $1 \mathrm{a}$ & $1 \mathrm{a}$ \\
\hline 44 & $99 \mathrm{a}$ & $98 \mathrm{a}$ & $92 \mathrm{a}$ & $23 \mathrm{c}$ & $1.6 \mathrm{a}$ & $2.2 \mathrm{~b}$ & $2.8 \mathrm{~b}$ & $3.3 \mathrm{a}$ & $9.9 \mathrm{a}$ & $5.2 \mathrm{~b}$ & $1 \mathrm{a}$ & $1 \mathrm{a}$ \\
\hline 91 & 99 a & $99 \mathrm{a}$ & $44 \mathrm{~d}$ & $21 \mathrm{~d}$ & $1.5 \mathrm{a}$ & $1.7 \mathrm{a}$ & $2.2 \mathrm{a}$ & $3.4 \mathrm{a}$ & $9.9 \mathrm{a}$ & $7.5 \mathrm{a}$ & $1 \mathrm{a}$ & $1 \mathrm{a}$ \\
\hline
\end{tabular}

*Means followed by the same letter in all columns do not statistically differ between each other by the Scott-Knott test, at $5 \%$ probability.

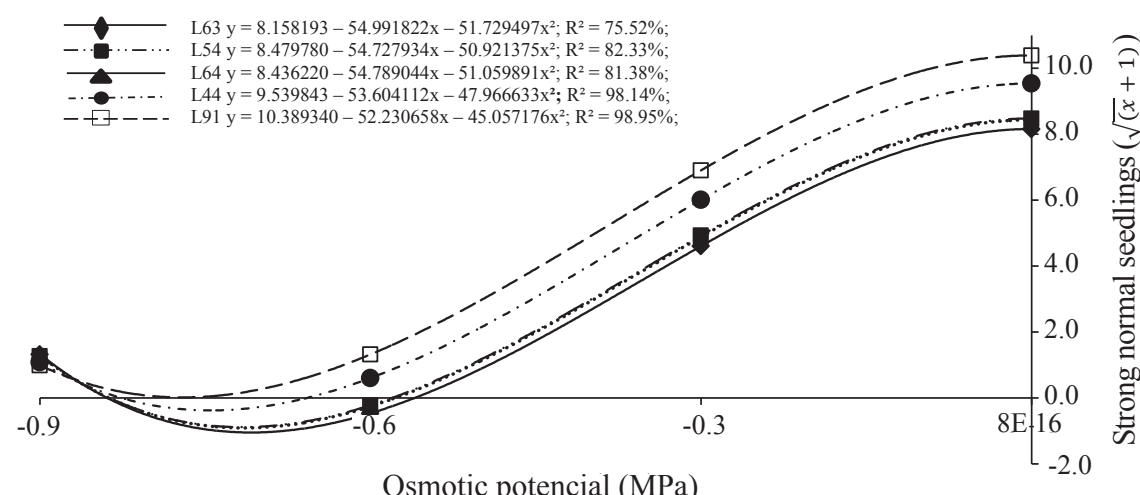

Figure 3. Strong normal seedlings originated from seeds of the maize lines $63,54,64$, 44, and 91, subjected to the osmotic potentials of $0.0,-0.3,-0.6$ and $-0.9 \mathrm{MPa}$.

Similar results to those found within this study were already reported by Moterle et al. (2008), who have found that water stress, induced by PEG 6000, reduced the percent of normal seedlings emerged in almost all popcorn hybrids by them assessed. Likewise, on evaluating performance of seeds of different maize hybrids grown under water stress conditions simulated by mannitol solution Avila et al. (2007) observed that under the osmotic potentials of $-0.3 \mathrm{MPa},-0.6$ $\mathrm{MPa}$, and $-0.9 \mathrm{MPa}$ there was reduction in the length of the assessed seedlings. In studies performed on physiological and biochemical aspects of soybean cultivars, Vieira, et al. (2013) also found similar results. Therefore, according to these authors, the greater the osmotic potential of solution the lesser will be water availability in the substrate and smaller will be total length of seedlings.

Through electrophoretic profiles of bands stained for $\alpha$-amylase enzyme contained in the seeds it is observable that in the treatment T0 $(0.0 \mathrm{MPa})$ there was a low expression of this enzyme in the seeds of all maize lines assessed (Figure 4A). However, on treatments T3 and T6 (-0.3 and -0.6 MPa) it is also possible to observe that there was a low expression of such enzyme in the seeds of all maize lines; but yet more sharply at the treatment $\mathrm{T} 9(-0,9 \mathrm{MPa})$ in seeds of the lines 44 and 91. Furthermore, on observing results obtained for seed germination of these two lines (Table 1), it can be seen that these two maize lines also had the worst results for this parameter. In this same context, Avila et al. (2007) state that, under water stress conditions, the good performance of maize seedlings in 
the field depend on the seed physiological potential. However, according to Oliveira et al. (2013), besides the genes coding for expression of $\alpha$-amylase enzyme, several other genes may be involved in the genetic trait for control of physiological quality of seeds, as for example, the genes encoding for expression of enzymes related to respiration; and this event would explain the low activity of such enzyme in the seeds of breeding lines regarded as high physiological quality. Therefore, these factors can explain the low germination percent of seeds of maize lines 91 and 44 obtained under osmotic potentials of -0.6 and $-0.9 \mathrm{MPa}$ and that showed the lowest germination percents on treatment T0 (0.0 MPa) (Table 1). $\begin{array}{ccccc}\text { T0 } & \text { T3 } & \text { T6 } & \text { T9 } \\ 63546444 & 91 & 6354644491 & 63 & 546444916354644491\end{array}$

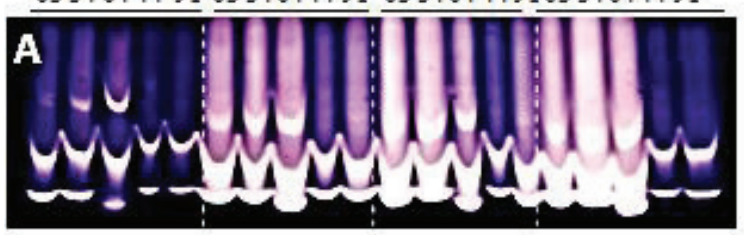

T0

$63546444916354644491 \quad 6354644491 \quad 6354644491$



6354644491635464449163546444916354644491

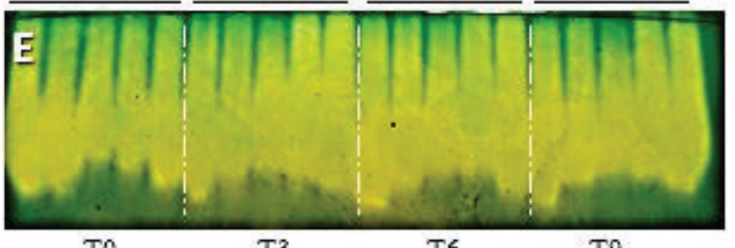

T0

6354644491635464449163546444916354644491

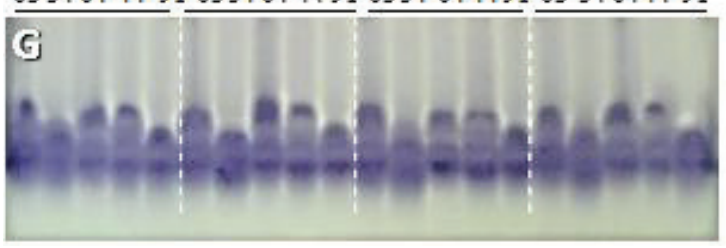

T0

T3

T6

T9

6354644491635464449163546444916354644491

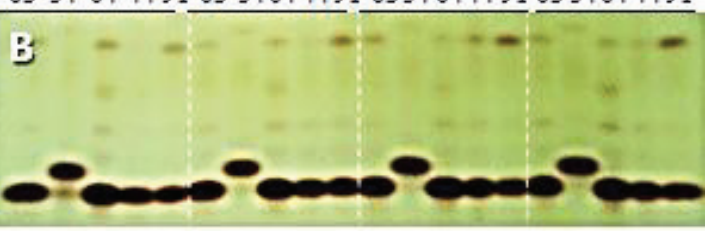

T0

T3

T6

T9

6354644491635464449163546444916354644491

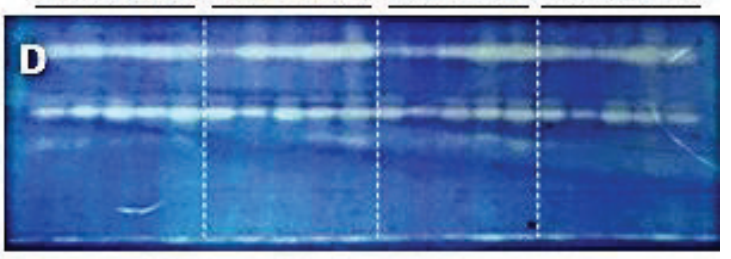

T0

T3

T6

T9

$635464449163546444916354644491 \underline{6354644491}$



T0

T3

T6

T9

6354644491635464449163546444916354644491

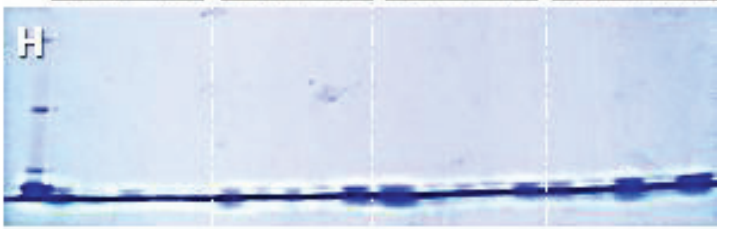

Figure 4. Electrophoretic profiles stained on polyacrylamide gel 7.5\% (separating gel) and $4.5 \%$ (stacking gel) for isozymes: $\alpha$-amylase (A) esterase (B) glutamate oxaloacetate transaminase (C) superoxide dismutase (D), catalase (E), alcohol dehydrogenase $(F)$, malate dehydrogenase $(\mathrm{G})$, and heat-resistant proteins $(\mathrm{H})$ extracted from seeds of five different the maize lines $(63,54,64,44$ and 91$)$, and subjected to four different osmotic potentials during germination. $\mathrm{T} 0=$ $0.0 \mathrm{MPa} ; \mathrm{T} 3=-0.3 \mathrm{MPa}, \mathrm{T} 6=-0.6 \mathrm{MPa}$ T $9=-0.9 \mathrm{MPa}$.

Generally, on the zymogram stained for EST enzyme (Figure 4B) it can be observed that there was an increase on intensity of bands whenever osmotic potential was reduced, especially for the maize line 91, and that the high activity of such enzyme is correlated to the higher efficiency of membranes system.

As the osmotic potential was reduced GOT enzyme has also shown increase on intensity of bands, mainly for the maize lines 64, 44, and 91 (Figure 4C). Such enzyme participates in the amino acids metabolism and in decarboxylation reactions via malic acid enzyme; and also on transformation of aspartate into oxaloacetic acid and malate, during carbon dioxide fixation by plants (Menezes et al., 2008).

Trough the electrophoretic profile stained for SOD enzyme it can be observed that there was a high activity of such enzyme in the seeds germinated under the water potential T0 (Figure 4D). Nevertheless, whenever osmotic potential was reduced there was also a reduction on intensity of the 
electrophoretic bands observed for the maize lines 63, 54, and 64, what did not occur on the bands observed for the lines 44 and 91. Likewise, in a study performed on transduction of the signs of salt and water stresses in plants, Zhu (2002) has also observed reduction on activity of SOD enzyme in plants grown under water stress.

As it may be seen on Figure 4E similar results were also observed for the CAT enzyme, which also had an increase on activity of such enzyme in the seeds of the maize lines 44 and 91, whenever osmotic potential was reduced. According to Deuner et al. (2011), tolerance to salt stress is correlated to synchronized activity of the antioxidant enzymes, which are liable for the removal of reactive oxygen species (ROS) from cells. These ROS are produced during natural metabolism of plants and have a regulation system between their production and removal from the cells, and may also be influenced by certain oxidative stress conditions (Apel and Hirt, 2004). Thereby, according to Rosa et al. (2005), the SOD and CAT enzymes might be considered as effective detoxification mechanisms, since they act on removal of ROS from cells.

On isoenzymatic profile stained for $\mathrm{ADH}$ enzyme (Figure 4F) it is observable that in the treatment T0 (0.0 $\mathrm{MPa}$ ) there was a greater expression of such enzyme in seeds of the maize line 44. Yet, generally, whenever osmotic potential was reduced there was an increase on activity of the ADH enzyme in seeds of all maize lines assessed. The increased activity of the ADH enzyme in seeds germinated under these conditions may be explained by the reduction in the oxygen availability, which may have caused activation of anaerobic respiration pathway. According to Torggler et al. (1995) in maize seeds the ADH enzyme have two closely linked loci (Adh1 and Adh2), which are directly correlated to the regulation of its gene expression for having a welldefined function under anaerobic conditions.

As it can be notice on Figure $4 \mathrm{G}$, it was not feasible to observe differences on intensity of bands stained for MDH enzyme present in seeds germinated under all osmotic potentials assessed. According to Goodman and Stuber (1987), production of this enzyme is correlated to aerobic cellular respiration, is encoded by five different loci, and is found in large amounts in different cell organelles, mitochondria, and cytoplasm. Moreover, in a study performed on the electrophoretic variants of the proteins and isozymes occurring during deterioration of maize seeds artificially aged, Brandão-Junior et al. (1999) found no correlation between activity of this enzyme and seed quality. Thus, any change in its expression by electrophoresis is only observed when the seeds have already gone through an advanced deterioration process, which makes this enzyme an inefficient marker in the indication of seed physiological quality.

As it can be observed on the zymogram stained for heat resistant proteins (Figure $4 \mathrm{H}$ ), there was no polymorphism enough to distinguish among the different maize lines assessed. This might have occurred due to fact that for extraction of such enzymes it was used parts of radicles originating from seeds in already too advanced imbibition process. However, there was a small increase on intensity of some bands of low molecular mass in the seeds of maize lines 63,64 , and 91 , on all osmotic potentials studied. Similar results were already reported by Albuquerque et al. (2009), who also observed a reduction in the expression of these proteins during imbibition process of timber tree "Tatabu" [Diplotropis purpurea (Rich.) Amsh.] seeds. According to Araújo et al. (1998) heat shock proteins (HSP) are typical of the stress caused by high temperatures; although its synthesis can also be induced by water stress. In addition, in a study carried out with different maize lines related to tolerance to stress caused by high temperatures or by water stress, Ristic et al. (1991) found that there were differences in the pattern of synthesis of the HSP; however only one of these enzymes, of circa $45 \mathrm{kDa}$ molecular mass was observed in the plants tolerant to both stress types. Thus, it was not possible to determine a specific band of these heat resistant proteins that might be used as electrophoretic markers for tolerance to water stress in seeds of any of the cultivars assessed.

\section{Conclusions}

Osmotic potential of $-0.9 \mathrm{MPa}$ affects the physiological quality and vigor of maize lines seeds.

Under water deficit, the best germination percent was observed in the line 63 .

Higher vigor by the T50 and normal strong seedlings tests is observed in the line 91 .

Higher expression of enzymes of the antioxidant system, catalase and superoxide dismutase is observed for lines 44 and 91 .

The line 91 can be considered as promising to the tolerance to the water stress.

\section{References}

ALFENAS, A.C. Eletroforese e marcadores bioquimicos em plantas e microrganismos. 2.ed.Viçosa, MG: UFV, 2006. 627 p.

ALBUQUERQUE, K.S.; GUIMARÃES, R.M.; ALMEIDA, I.F.; CLEMENTE, A.C.S. Alterações fisiológicas e bioquímicas durante a embebição de sementes de sucupira-preta (Bowdichia virgilioides Kunth.). Revista Brasileira de Sementes, v.31, n.1, p.249-258, 2009. http://www. scielo.br/pdf/rbs/v31n1/a28v31n1.pdf 
APEL, K.; HIRT, H. Reactive oxygen species: metabolism, oxidative stress and signal transduction. Annual Review of Plant Biology, v.55, p.373-399, 2004. http://www.heribert-hirt.info/pdf/prr85_ros.pdf

ARAÚJO, J.L.S.; MARGIS-PINHEIRO, M.; RUMJANEK, N.G. Proteinas de choque térmico e tolerância a altas temperaturas em plantas. Seropédica: Embrapa Agrobiologia, 1998. 27 p. (Embrapa-CNPAB. Documentos, 80). http://www.cnpab.embrapa.br/system/files/downloads/doc080.pdf

AVILA, M.R.; BRACCINI, A.L.; SCAPIM, C.A. Teste de comprimento de plântulas sob estresse hídrico na avaliação do potencial fisiológico das sementes de milho. Revista Brasileira de Sementes, v.29, n.2, p.117-124, 2007. http://www.scielo.br/pdf/rbs/v29n2/v29n2a16.pdf

BRANDÃO JUNIOR, D.S.; CARVALHO, M.L.M.; VIEIRA, M.G.G.C. Variações eletroforéticas de proteínas e isoenzimas relativas à deterioração de sementes de milho envelhecidas artificialmente. Revista Brasileira de Sementes, v.21, n.1, p.114-121, 1999. http://www.abrates.org.br/revista/artigos/1999/v21n1/artigo17.pdf

DEUNER, C.; MAIA, M.S.; DEUNER, S.; ALMEIDA, A.S.; MENEGHELLO, G.E. Viabilidade e atividade antioxidante de sementes de genótipos de feijãomiúdo submetidos ao estresse salino. Revista Brasileira de Sementes, v. 33, p. 711-720, 2011. http://www.scielo.br/pdf/rbs/v33n4/13.pdf

FARIA, M.A.V.R.; VON PINHO, R.G.; VON PINHO, E.V.R.; GUIMARÃES, R.M.; FREITAS, F. E.O. Qualidade fisiológica de sementes de milho colhidas em diferentes estádios de linha de leite. Revista Brasileira de Milho e Sorgo, v.1, n.1, p.93-104, 2002. http://rbms.cnpms.embrapa. br/index.php/ojs/article/view/14

FERREIRA, D.F. SISVAR: a computer statistical analysis system. Ciência e Agrotecnologia, v.35, n. 6, p. 1039-1042, 2011. http://www.scielo.br/pdf/ cagro/v35n6/a01v35n6.pdf

GOODMAN, M.M.; STUBER, C.W. Mayze. In: TANKSLEY, S. D.; ORTON, T. J. Isoenzymes in plants genetics and breeding. Amsterdam: Elsevier, 1987. p. 1-33.

KRANNER, I.; MINIBAYEVA, F.V.; BECKETT, R.P.; SEAL, C.E. What is stress? Concepts, definitions and applications in seed science. New Phytologist, v.188, p.655-673, 2010. http://www.ncbi.nlm.nih.gov/pubmed/20854396

MANIVANNAN, P.; JALEEL, C.A.; SOMASUNDARAM, R.; PANNEERSELVAM, R. Osmoregulation and antioxidant metabolism in droughtstressed Helianthus annuus L. under triadimefon drenching. Comptes Rendus Biologies, v.331, p.418-425, 2008. http://www.sciencedirect.com/science/ article/pii/S1631069108000826

MENEZES, M.; VON PINHO, E.V.R.; PEREIRA, A.M.A.R.; OLIVEIRA, J.A. Identificação de cultivares de milho, feijão, algodão e soja por meio de enzimas e proteínas resistentes ao calor. Revista Brasileira de Sementes, v.30, n.2, p.111122, 2008. http://www.scielo.br/pdf/rbs/v30n2 /a14v30n2.pdf

MOTERLE, L.M.; SCAPIM, C.A.; BRACCINI, A.L.; RODOVALHO, M.A.; BARRETO, R.R. Influência do estresse hídrico sobre o desempenho fisiológico de sementes de híbridos simples de milho-pipoca. Ciência e Agrotecnologia, v.32, n.6, p.1810-1817, 2008. http://www.scielo.br/pdf/cagro/v32n6/v32n6a20.pdf

NOCTOR, G.; FOYER, C.H. Ascorbate and glutathione: keeping active oxygen under control. Annual Review of Plant Physiology and Plant Molecular Biology, v.49, p.249-279, 1998. http://www.annualreviews.org/doi/ abs/10.1146/annurev.arplant.49.1.249

OLIVEIRA, G.E.; VON PINHO, R.G.; ANDRADE, T.; VON PINHO, E.V.R.; SANTOS, C.D.; VEIGA, A.D. Physiological quality and amylase enzyme expression in maize seeds. Ciência e Agrotecnologia, v.37, n.1, p.4048, 2013. http://www.scielo.br/pdf/cagro/v37n1/05.pdf
REDDY, A.R.; CHAITANYA, K.V.; VIVEKANANDAN, M. Droughtinduced responses of photosynthesis and antioxidant metabolism in higher plants. Journal of Plant Physiology, v. 161, p.1189-1202, 2004. http://www. sciencedirect.com/science/article/pii/S0176161704000422

RESENDE, K.F.M.; SANTOS, F.M.C.; DIAS, M.A.D.; RAMALHO, M.A.P. Implication of the changing concept of genes on plant breeder's work. Crop Breeding and Applied Biotechnology, v. 11, n.4, p.345-351, 2011. http:// www.scielo.br/scielo.php?pid=S1984-70332011000400008\&script=sci_arttext\&tlng=en

RISTIC, Z.; GIFFORD, D.J.; CASS, D.D. Heat shock proteins in two lines of Zea mays L. that differ in drought and heat response. Plant Physiology, v.97, p.1430-1434, 1991. http://www.ncbi.nlm.nih.gov/pmc/articles/PMC1081182/

ROSA, S.D.V.F.; VON PINHO, E.V. R.; VIEIRA, E.S.N.; VEIGA, R.D.; VEIGA, A.D. Enzimas removedoras de radicais livres e proteínas lea associadas à tolerância de sementes milho à alta temperatura de secagem. Revista Brasileira de Sementes, v.27, n.2, p.91-101, 2005. http://www.scielo.br/pdf/ $\mathrm{rbs} / \mathrm{v} 27 \mathrm{n} 2 / \mathrm{a} 14 \mathrm{v} 27 \mathrm{n} 2 . \mathrm{pdf}$

SOUZA, R.; SCHONS, J.; BRAMMER, S.P.; PRESTES, A.M.; SCHEEREN, P.L.; SÓ E SILVA, M.; DUCA, L.J.A.D. Atividade isoenzimática em plantas de trigo infectadas com o vírus SBWMV. Pesquisa Agropecuária Brasileira, v.40, n.9, p.845-852, 2005. http://www.scielo.br/scielo.php ?pid=S0100-204 X2005000900002\&script=sci_arttext

THAKUR, M.; SHARMA, A.D. Salt-stress-induced proline accumulation in germinating embryos: evidence suggesting a role of proline in seed germination. Journal of Arid Environments, v. 62, p.517-523, 2005. http:// ac.els-cdn.com/S0140196305000236/1-s2.0-S0140196305000236-main. pdf?_tid=bbc62d40-0779-11e3-a0f0-00000aab0f6c\&acdnat=1376770697_2 $1 \mathrm{~d} 317 \mathrm{e} 94 \mathrm{bd} 537 \mathrm{de} 7824 \mathrm{e} 16 \mathrm{ebcec} 44 \mathrm{e} 2$

TORGGLER, M.G.F.; CONTEL, E.P.B.; TORGGLER, S. P. Isoenzimas: variabilidade genética em plantas. Ribeirão Preto: Sociedade Brasileira de Genética, 1995. 186 p.

VAZ MELO , A.; SANTOS, L. D. T.; FINOTO, E. L.; DIAS, D. C. F. S.; ALVARENGA, E. M. Germination and vigor of popcorn seeds submitted to thermal and water stress. Bioscience Journal, v.28, p.687-695, 2012. http:// apps.webofknowledge.com.ez26.periodicos.capes.gov.br/full_record.do?product $=$ UA\&search mode $=$ GeneralSearch\&qid $=10 \& S I D=2$ FeyEw5ATPc22nQzRMZ\&page $=1 \&$ doc $=1$

VIEIRA, F.C.F.; SANTOS, C.D.; NOGUEIRA, A.P.O.; DIAS, A.C.C.; HAMAWAKI, O.T.; BONETTI, A.M.; Physiological and biochemical aspects of soybean cultivars submitted to water deficit induced by PEG 6000. Bioscience Journal, v.29, p.542-551, 2013. http://apps.webofknowledge.com.ez26.periodicos.capes.gov.br/full record.do?product=UA\&search_mode $=$ GeneralSearch \& qid $=5 \&$ SID $=2$ FeyEw 5 ATPc22nQzRMZ\&page $=1 \&$ doc $=1$

VILLELA, F.A.; DONI FILHO, L.; SEQUEIRA, E.L. Tabela de potencial osmótico em função da concentração de polietilenoglicol 6000 e da temperatura. Pesquisa Agropecuária Brasileira, v.26, p.1957-1968, 1991. http://seer.sct.embrapa.br/index.php/pab/article/view/3549/882

ZHU, J.K. Salt and drought stress signal transduction in plants. Annual Review of Plant Biology, v.53, p. 247-273, 2002. http://www.ncbi.nlm.nih. gov/pmc/articles/PMC3128348/ 